\title{
SEDIMENTARY DYNAMICS AND STRUCTURAL CONTROL OF NEOGENE TROPICAL BIOFACIES DURING THE FORMATION OF THE CENTRAL AMERICAN ISTHMUS
}

COATES*, Anthony; OBANDO, Jorge, and GONZALEZ, Herman, Center for Paleoecology, Smithsonian Tropical Research Institute, Apartado 2072,Balboa, Republic of Panama

The central evolutionary, ecological and paleoceanographic questions of the American tropical Neogene relate to how and during what time the Central American Isthmus formed. Geographically, closure was located between the southern edge of the Chortis Block in southern Nicaragua and the Atrato Valley in Colombia. In this region we describe, on the Caribbean side, five Neogene sedimentary basins. They are the Atrato, Chucunaque, Gatun, Bocas del Toro, and Limon Basins. On the Pacific side the Neogene sediments formed as part of the Central American Trench and are well exposed in a series of uplifted blocks on the Nicoya, Osa and Burica Peninsulas. Our analysis allows 1) a construction of the sequence of contrasting sedimentary environments which characterize the different basins, giving a composite geological history of the isthmus for the Late Neogene and 2) identifies the comparable biofacies from the different basins which allow and constrain the evolutionary and ecological questions to be posed concerning the effect of the isthmus as a biogeographic barrier. Temporally, from it's partial emergence in the Middle Miocene, the isthmus shallows by the Early Pliocene (3.5-3.4 Ma) to less than $50 \mathrm{~m}$ (Duque-Caro, 1990) when there is a marked differentiation of shelf marine macrobenthic species between the Caribbean and the Pacific. The evidence from reliably dated, large, diverse exchanges of North and South American vertebrates on land constrains the final closure date to not later than 2.8-2.5 Ma (Marshall, 1988). Given that no conclusive evidence for final closure can come exclusively from a study of sedimentary facies, when depths of less than $50 \mathrm{~m}$ are involved, the present window of almost $1 \mathrm{Ma}$, during which final closure must have occurred, will only be narrowed further by the detailed study of very shallow-water fossil clades and complementary molecular data. Present studies indicate that such clades are abundantly preserved. 